\title{
Bacterial contamination of cotton as an indicator of respiratory effects among card room workers
}

\author{
R. RYLANDER ${ }^{1}, H . R$. IMBUS ${ }^{2}, A_{N D} M . W . S U H^{2}$ \\ From the ${ }^{1}$ Department of Environmental Hygiene, University of Gothenburg, Sweden, and ${ }^{2}$ Burlington \\ Industries, Greensboro, North Carolina, USA
}

ABSTRACT The influence of the bacterial contamination of cotton dust on the development of pulmonary symptoms has been investigated. The pulmonary function of card room workers in 23 US cotton mills was tested before and after the Monday working shift. A significant relation was found between the $\triangle F E V_{1.0}$ decrement and the vertical elutriator dust level in the different mills. An improved correlation was obtained when the number of Gram-negative bacteria cultured from the bale cotton used in the different mills was employed in the exposure description. The results support earlier epidemiological and experimental studies, which demonstrate the importance of the Gramnegative bacteria in the development of pulmonary symptoms among workers in cotton mills.

Several research workers have investigated the importance of the bacterial contamination of cotton dust in the development of pulmonary symptoms. Schneiter et al. (1942) cultured bacteria from samples of different cotton products in various mills and reported that the samples contained Gram-negative bacteria. An endotoxin-like substance was demonstrated in filtrates from saline extracts of stained cotton. Pernis et al. (1961) and Cavagna et al. (1969) suggested bacterial endotoxins as the causative agent in occupational disease arising from the inhalation of vegetable dusts, particularly dust from cotton.

A close correlation between the number of Gramnegative bacteria in the air and the prevalence of byssinotic symptoms has been demonstrated in a questionnaire study of card room workers (Cinkotai et al., 1977).

The present study was undertaken to investigate whether the bacterial contamination of bale cotton in different cotton mills could serve as an indicator of the extent of pulmonary reactions among people working in the card rooms. The number of bacteria was determined by culturing samples of the bale cotton used in the different mills. The prevalence of pulmonary reaction was evaluated by determining the one-second forced expiratory volume $\left(\mathrm{FEV}_{1 \cdot 0}\right)$ before and after the working shift.

Received for publication 4 August 1978

Accepted for publication 20 December 1978

\section{Materials and methods}

PLANT DESCRIPTION

Twenty-three different cotton plants located in five different States in the US were investigated for a period of 2 years. The mills were processing pure cotton or cotton blended with up to $65 \%$ synthetic material. The population studied comprised those who worked in the carding departments (carding, drawing and roving) at the time of the investigation.

\section{PULMONARY FUNCTION TESTS}

Determinations of FEV $_{\mathbf{1}} \cdot \mathbf{0}$ were made by occupational health nurses employed in the different mills. A waterless spirometer (Jones Pulmonor) was used to measure $\mathrm{FEV}_{1 \cdot 0}(\mathrm{ml} / \mathrm{s})$. Standardisation of spirometers was accomplished with a $1000 \mathrm{ml}$ syringe using a three-way valve to inject $1000 \mathrm{ml}$ increments of air into the spirometer. The workers were tested before reporting to work at the beginning of the shift on the first day of the week and retested approximately $6 \mathrm{~h}$ after the beginning of the shift. At each testing, four tracings were taken for each worker. The mean of the two highest readingswas used as the FEV $1 \cdot 0$ value for that test. The average $\triangle F E_{1 \cdot 0}\left(=F E V_{1 \cdot 0}\right.$ after work - FEV ${ }_{1.0}$ before work) was calculated from the values recorded before and during the shift. Results from all individuals with a greater than $50 \%$ gain or loss in $\triangle F E V_{1.0}$ were omitted in calculating the plant averages (about $5 \%$ of all values obtained). For each plant, the mean $\triangle F_{E V} \cdot 0$ was calculated 
from the values of all the workers.

With few exceptions, workers were not wearing respirators during the study, although this later became necessary in several cases in order to meet Federal Standards after the dust levels were known.

Questionnaires were given to workers to determine the prevalence of symptoms of byssinosis. The prevalence of classical symptoms of byssinosis was found to be less than $1 \%$ and could not be used as a value in the subsequent analysis.

\section{DUST MEASUREMENTS}

The dust levels in the card rooms were determined using vertical elutriators with a sampling rate of $7 \cdot 21$ litre/min. By definition, particles with an aerodynamic diameter of $15 \mu \mathrm{m}$ or more are thus not included in the recorded values. In general, 12 measurements were made in each of the different card rooms.

\section{BACTERIAL CONTAMINATION}

Samples of the bale cotton regularly used in the different mills were shaken in $60 \mathrm{ml}$ of sterile saline. The liquid was then squeezed out, the cotton put back into the fluid and shaken again. This process was repeated five times, taking about 5 minutes. Serial dilutions of the washing liquid were prepared and inoculated in Drigalski agar pour plates, a medium which facilitates the growth of Gramnegative rods. The plates were incubated overnight at $37^{\circ} \mathrm{C}$ and the number of colony-forming units (cfu) was counted. The results were expressed as the $\log$ number of Gram-negative bacteria per gram bale cotton. Practical considerations precluded determination of the number of airborne bacteria.

ANALYSIS OF DATA

In the analysis of the data the relationship between the $\triangle F E V_{1.0}$ value and the level of exposure to airborne dust and bacteria in the bale cotton was calculated.

Because the data on the bacterial contamination of the bale cotton were not a direct measure of the exposure dose, three models to describe the relationship between bale cotton bacteria and airborne bacteria were tested. In these models the number of bacteria in the cotton, the dust level and the blending ratio were combined to make up the independent variables.

Weighted and unweighted regression analyses were performed for each of the three models proposed. Several algebraic transformations and linear and quadratic functions were applied to the bacterial count to obtain the model which best fitted the existing data. The influence of the number of workers in each plant on the relationship was tested using weighted regressions. The details of the models used are reported in Appendix I.

\section{Results}

The workers from the different plants participating in the study numbered 2712 in 1976 and 3896 in 1977. A major reason for the difference in number was that in 1976 the selection of cotton samples for bacterial determination function surveys was started when some plants had already carried out their annual pulmonary examinations of workers, whereas all plants were included in the 1977 study.

The results of the $\mathrm{FEV}_{1.0}$ determinations, the dust measurements, the cotton blend ratio and the determinations of the number of Gram-negative bacteria are reported in Appendix II.

Large variations were found in $\triangle F V_{1.0}$ during the work shift at the different plants $(+75$ to -139 $\mathrm{ml} / \mathrm{s}$ ). The dust levels ranged from 0.14 to 1.35 $\mathrm{mg} / \mathrm{m}^{3}$ and the log number of Gram-negative bacteria in the different bale cottons varied from 1.4 to 6.7 .

The relationship between $\triangle \mathrm{FEV}_{1 \cdot 0}$ and dust levels in the card rooms was calculated using regression analyses weighted for the number of employees in each plant. The results (Table 1) show that the relationship was statistically significant, varying between the $1 \%$ and $5 \%$ levels.

Weighted regression analyses based on the number of workers in each plant were found to give higher correlation coefficients between $\triangle F E V_{1.0}$ values and the bacterial contamination. The use of the quadratic model did not improve the correlation and was discarded.

Table 2 compares the simple correlation coefficients from the weighted regression. Analyses were made for the 1976 and 1977 data separately and then combined. Within each column, the coefficients can be directly compared. For any two different columns, the error degrees of freedom must be considered before the two coefficients can be compared. The statistical significance of the coefficients are shown at $5 \%$ and $1 \%$ error levels. The results show that a significant correlation can be demonstrated between average $\triangle F V_{1 \cdot 0}$ values in the

Table 1 Relationship between $\triangle F E V_{1.0}$ and dust level in card rooms

\begin{tabular}{lrrr}
\hline Statistics & \multicolumn{2}{l}{ Year } \\
\cline { 2 - 4 } & 1976 & 1977 & $1976+1977$ \\
\hline r & 0.49 & 0.52 & 0.50 \\
Error degrees of freedom & 15 & 20 & 37 \\
Significance level \% & 5 & 5 & 1 \\
\hline
\end{tabular}


Table 2 Values of simple correlation coefficients for $\triangle F E V_{1.0}$ values and bacterial exposure from weighted regression analyses

\begin{tabular}{lllll}
\hline Model & Form of $x$ & 1976 & 1977 & $1976+1977$ \\
\hline I & $\log _{10} \mathrm{NP}$ & $0.49^{*}$ & $0.58^{*}$ & $0.47^{* *}$ \\
& $\sqrt{\mathrm{NP}}$ & $0.62^{* *}$ & $0.60^{* *}$ & $0.60^{* *}$ \\
II & $\log _{10} \mathrm{ND}$ & $0.55^{*}$ & $0.60^{* *}$ & $0.51^{* *}$ \\
& $\sqrt{\mathrm{ND}}$ & $0.60^{* *}$ & $0.62^{* *}$ & $0.61^{* *}$ \\
III & $\log _{10} \mathrm{ND}^{\prime}$ & $0.54^{*}$ & $0.63^{* *}$ & $0.52^{* *}$ \\
& $\sqrt{\mathrm{ND}}$ & $0.60^{* *}$ & $0.63^{* *}$ & $0.62^{* *}$ \\
(Error degrees of freedom) & $(15)$ & $(20)$ & $(37)$ \\
\hline
\end{tabular}

* Significant at $1 \%<P<5 \%$ * Significant at $P<1 \%$.

different plants and the bacterial exposure expressed by any of the three models used. A slightly higher significance is found for model III which relates $\triangle \mathrm{FEV}_{1 \cdot 0}$ to the levels of dust from cotton, exclusive of synthetic dust.

The square root form for the exposure parameter (Gram-negative bacteria $\times$ blend ratio or dust) was found to be superior to the logarithmic form of the untransformed product. This can be confirmed by comparing the correlation coefficients in Table 2. Based on this transformation, the estimated regression equation for model III is as follows for the combined data from 1976 and 1977:

$$
\begin{gathered}
\triangle \mathrm{FEV}_{1.0}=-15.43-0.08169 \sqrt{\mathrm{ND}^{\prime}} \\
(\mathrm{R}=0.62 ; \text { Error df }=37 ; \mathrm{P}<0.01)
\end{gathered}
$$

The equation is illustrated in the Figure.

\section{Discussion}

The technique applied in the present study to determine the decrease in the ventilatory function of card room workers is a standard method which has been used by several other authors (Imbus and Suh, 1973; Merchant et al., 1975). It can be argued that the sophistication of the measurement, performed by the occupational health nurses, is less than that of similar measurements carried out in pulmonary laboratories. On the other hand, the conditions in the present study represent the conditions in continuous routine checking programmes on cotton dust effects. The methods used to determine airborne dust and the number of bacteria in the different cottons are also routine procedures.

The reason for the low prevalence of classical byssinosis was not analysed in detail. Possible explanations are the fact that workers with symptoms were often transferred to less exposed working positions, that workers who were previously less exposed were selected for work in dusty areas, and the rather high turnover of workers.

The scatter of data points around the regression

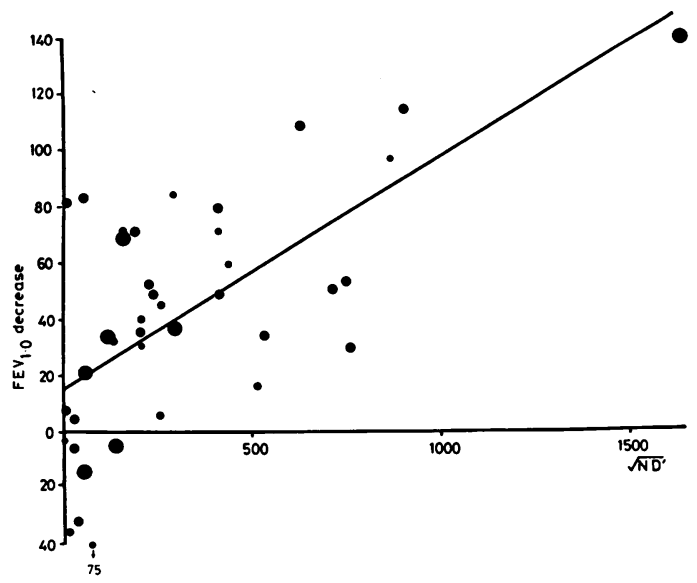

Figure Relationship between $\triangle F E V_{1.0}$ values in $\mathrm{ml}$ and $\sqrt{N^{\prime}}$ for 1976 and 1977 ( $N=$ Gram-negative bacteria/g bale cotton; $D^{\prime}=$ cotton dust level $\mathrm{mg}$ ). Line indicates best regression fit applying model III (see Appendix I). Regression weighted for number of employees in each plant, which is also proportional to the size of dot. $\triangle F E V_{1.0}=-15.43-0.082 \sqrt{ } \overline{N D^{\prime}} ;$ correlation coefficient $0.62(\mathrm{P}<0.01)$.

line, illustrated in the Figure, may be attributable to several factors. The timing of pulmonary function tests, cotton dust sampling and sampling of cotton for bacteria counting did not coincide. Variation of one or more of these three factors with respect to time would have contributed to the error. An additional error arises from the nature of the study design, which necessitated the use of conceptual models for the bacterial exposure. This design was employed in an effort to relate the bacterial count in raw cotton to that inhaled by exposed workers. An experiment where these factors are controlled would be a step toward further substantiation of a possible cause and effect relationship.

Statistically significant correlations were found 
between $\triangle F E V_{1 \cdot 0}$ values and dust levels. The correlation improved when the bacterial contamination was included as an exposure variable.

The relationship between the number of Gramnegative bacteria and the appearance of pulmonary effects is consistent with findings reported earlier by Cinkotai et al. (1977). The number of Gramnegative bacteria was determined in this study by direct sampling from the air in the mills, using an Andersen sampler. A close relationship was found between the prevalence of byssinosis in different mills and the number of airborne viable Gramnegative bacteria.

The similarity between the principal results obtained here and epidemiological studies currently being performed in different countries using different experimental methods further supports the hypothesis concerning a relationship between exposure to Gram-negative bacteria and the development of chronic respiratory disease.

The bacterial contamination of cotton has been studied by Rylander and Lundholm (1977). They found that cotton contained a large proportion of Gram-negative bacteria mainly of the genera Enterobacter, Klebsiella, Acinetobacter and Agrobacterium.

Experiments on animals have demonstrated that a large increase in the number of polymorphonuclear leucocytes (PMN) takes place in the airways of animals exposed to Enterobacter and Klebsiella. No reaction could be detected after the exposure to bacilli and fungi cultured from cotton samples.

Acute exposure to water extracts of bale cotton, bract or a bract aerosol will cause an increase in the number of PMN in the airways of animals a few hours after exposure (Rylander and Nordstrand, 1974). During a three-week exposure the number of PMN remained high but then fell within a few days of cessation of exposure (Rylander et al., 1975). The leucocyte reaction is not species-specific but occurs in several different animal species (Walker et al., 1975) and in man (Merchant et al., 1975).

The appearance of symptoms in humans after exposure to airborne Gram-negative bacteria may be related to the endotoxin content of the bacteria. The inhalation of endotoxins will activate several physiological and pathological reactions in the body (Kadis et al., 1971). Acute exposure causes acute symptoms, such as fever, chills and malaise. Endotoxins activate complement through the properdin pathway. In this process, anaphylatoxins and chemotoxins are liberated, together with leucotactic factors which cause an influx of PMN into the exposed tissue (Mergenhagen et al., 1973). Histamines are also liberated and may cause constriction of the airways.

Prolonged exposure to endotoxins will result in the development of tolerance (Wolff, 1973), which explains the disappearance of mill fever among workers in cotton mills.

In conclusion, the data reported in this investigation demonstrate a correlation between the Gramnegative bacterial contamination of cotton dust and the developinent of airway constriction. Although a model for the reaction pattern can be suggested against the background of data from available literature, further studies are needed before the pathogenesis of byssinosis can be ascertained.

\section{References}

Cavagna, G., Foa, V., and Vigliani, E. C. (1969). Effects in man and rabbits of inhalation of cotton dusts or extracts and purified endotoxins. British Journal of Industrial Medicine, 26, 314-321.

Cinkotai, F. F., Lockwood, M. G., and Rylander, R. (1977). Airborne micro-organisms and prevalence of byssinotic symptoms in cotton mills. American Industrial Hygiene Association Journal, 38, 554-559.

Imbus, H. R., and Suh, M. W. (1973). Byssinosis: a study of 10133 textile workers. Archives of Environmental Health, 26, 183-191.

Kadis, S., Wienbaum, G., and Ajl, S. J. (1971). Bacterial endotoxins. In Microbial Toxins, V, pp. 1-492. Academic Press: London and New York.

Merchant, J. A., Halprin, G. G., Hudson, A. R., Kilburn, K. H., McKenzie, W. N., Hunt, D. J., and Bermazohn, P. (1975). Responses to cotton dust. Archives of Environmental Health, 30, 222-229.

Mergenhagen, S. E., Snyderman, R., and Phillips, J. K.(1973). Activation of complement by endotoxin. In Bacterial Lipopolysaccharides, pp. 78-82. Edited by E. H. Kass and S. M. Wolff. Chicago University Press: Chicago.

Pernis, B., Vigliani, E. C., Cavagna, G., and Finulli, M. (1961). The role of bacterial endotoxins in occupational diseases caused by inhaling vegetable dusts. British Journal of Industrial Medicine, 18, 120-129.

Rylander, R., and Nordstrand, A. (1974). Pulmonary cell reactions after exposure to cotton dust extract. British Journal of Industrial Medicine, 31, 220-223.

Rylander, R., Nordstrand, A., and Snella, M.-C. (1975). Bacterial contamination of organic dusts: effects on pulmonary cell reactions. Archives of Environmental Health, 30, 137-140.

Rylander, R., and Lundholm, M. (1977). Bacteria on cotton with special reference to dust inhalation effects. Proceedings of the 1977 Beltwide Cotton Production Research Conference, Atlanta, Georgia, Jan 10-12, pp. 67-70. Edited by P. J. Wakelyn and P. E. Sasser. National Cotton Council of America: Memphis, Tennessee.

Schneiter, R., Neal, P. A., and Caminita, B. H. (1942). Etiology of acute illness among workers using low-grade stained cotton. American Journal of Public Health, 32, 1345-1352.

Walker, R. F., Edison, G., and Hatcher, J. D. (1975) Influence of cotton dust inhalation on free lung cells in rats and guinea pigs. Laboratory Investigation, 33, 28-32.

Wolff, S. M. (1973). Biological effects of bacterial endotoxins in man. In Bacterial Lipopolysaccharides, pp. 251-256. Edited by E. H. Kass and S. M. Wolff. Chicago University Press: Chicago. 


\section{Appendix I}

\author{
MODEL DESCRIPTION FOR BACTERIAL \\ EXPOSURE
}

\section{Model I: Gram-negative bacterial count $\times$ blend ratio}

It is assumed that the original bacterial count in raw cotton is diluted according to the amount of blended polyester. Further, it is assumed that the density of bacteria in the working environment air, as well as the number inhaled by humans, is proportional to the diluted count in the blended raw material. This model ignores a possible additional contribution by dust levels.

Model II: Gram-negative bacterial count $\times$ dust level

The number of bacteria in the working environment and that inhaled by humans are assumed to be proportional to the level of respirable dust in the air for any given type of cotton with a fixed level of bacterial count. Therefore, the product (bacterial count $x$ dust) is used as an index of dose level. As the dust level is affected directly by the blend ratio, the latter is assumed to be a redundant factor. Although dust particles are thought to be the media for transporting bacteria, other bacteria in the air (not on dust, or on dust but not captured by the air filter) are also assumed to be proportional to the product (Gram-negative bacterial count $\times$ dust level).

Model III: Gram-negative bacterial count $\times$ level of pure cotton dust

The same as II except that the measured dust is adjusted to exclude the polyester dust blended with cotton. The model requires a formula for obtaining pure cotton dust as a function of blend ratio and total respirable dust.

MODEL COMPONENTS

$y=\triangle F V_{1.0}$ average $(\mathrm{ml})$ for workers in the plant.

$\mathrm{N}=$ number of Gram-negative bacteria $\left(=10^{\mathrm{z}}\right.$; $\left.\mathrm{Z}=\log _{10} \mathrm{~N}\right)$.

$\mathbf{P}=$ blend ratio $(=0.01 \times \%$ cotton blended $)$.

$\mathrm{D}=$ total respirable dust $\left(\mathrm{mg} / \mathrm{m}^{3}\right)$ measured by vertical elutriator.

$D^{\prime}=$ pure respirable cotton dust $\left(\mathrm{mg} / \mathrm{m}^{3}\right)$ exclusive of polyester dust $=\mathrm{D}\left[1-(1-\mathrm{P}) \mathrm{e}^{-1 \cdot 4 \mathrm{P}}\right]$; (equation from an unpublished (1977) Burlington study on blend ratio vs. dust level).

$\mathrm{e}=$ error (residual) of regression.

The regression models (unweighted forms only) and the two forms of transformation on independent variable were as follows:

$$
y=a+b x+e \text { (linear) }
$$$$
y=a+b x+c x^{2}+e \text { (quadratic) }
$$

with $x=\log _{10}(\mathrm{NP}), \log _{10}$ (ND) and $\log _{10}\left(\mathrm{ND}^{\prime}\right)$

$\mathrm{x}=\sqrt{\mathrm{NP}}, \sqrt{\mathrm{ND}}$ and $\sqrt{\mathrm{ND}^{\prime}}$,

respectively, for Models I, II and III.

The weighted regression was performed after applying the square root of the number of employees in each plant to the above linear and quadratic models. 


\section{Appendix II}

SUMMARY RA W DATA

Different plants included in investigations in 1976 and 1977, with number of workers, blend ratio, dust levels, log number of Gram-negative bacteria per gram of bale cotton and average change in $\triangle F E V_{1.0}$ over the working shift. After-shift values in excess of $\pm 50 \%$ are not included. Dust levels and average levels in carding, drawing and roving using the vertical elutriator.

\begin{tabular}{|c|c|c|c|c|c|c|}
\hline Plant & Year & Workers & $\begin{array}{l}\text { Blend ratio } \\
(\% \text { cotton })\end{array}$ & $\begin{array}{l}\text { Dust } \\
\left(m g / m^{2}\right)\end{array}$ & G-neg & $\triangle F E V_{1.0}$ \\
\hline $\begin{array}{l}1 \\
1\end{array}$ & $\begin{array}{l}76 \\
77\end{array}$ & $\begin{array}{l}34 \\
30\end{array}$ & $\begin{array}{l}50 \\
50\end{array}$ & $\begin{array}{l}0.50 \\
0.91\end{array}$ & $\begin{array}{l}5 \cdot 7 \\
5 \cdot 4\end{array}$ & $\begin{array}{l}-59 \\
-71\end{array}$ \\
\hline $\begin{array}{l}2 \\
2\end{array}$ & $\begin{array}{l}76 \\
77\end{array}$ & $\begin{array}{l}27 \\
26\end{array}$ & $\begin{array}{l}100 \\
100\end{array}$ & $\begin{array}{l}0.69 \\
0.31\end{array}$ & $\begin{array}{l}5 \cdot 1 \\
4 \cdot 3\end{array}$ & $\begin{array}{r}-84 \\
75\end{array}$ \\
\hline 3 & 77 & 62 & 85 & 0.76 & $4 \cdot 9$ & -49 \\
\hline 4 & 77 & 60 & 53 & 0.29 & $6 \cdot 1$ & -34 \\
\hline 5 & 77 & 68 & 75 & 0.76 & $5 \cdot 4$ & -33 \\
\hline $\begin{array}{l}6 \\
6\end{array}$ & $\begin{array}{l}76 \\
77\end{array}$ & $\begin{array}{l}49 \\
51\end{array}$ & $\begin{array}{l}50 \\
50\end{array}$ & $\begin{array}{l}0.43 \\
0.44\end{array}$ & $\begin{array}{l}4.9 \\
5.9\end{array}$ & $\begin{array}{l}-71 \\
-16\end{array}$ \\
\hline $\begin{array}{l}7 \\
7\end{array}$ & $\begin{array}{l}76 \\
77\end{array}$ & $\begin{array}{l}28 \\
20\end{array}$ & $\begin{array}{l}50 \\
50\end{array}$ & $\begin{array}{l}0.20 \\
0.14\end{array}$ & $\begin{array}{l}6 \cdot 7 \\
5 \cdot 6\end{array}$ & $\begin{array}{l}-96 \\
-36\end{array}$ \\
\hline $\begin{array}{l}8 \\
8\end{array}$ & $\begin{array}{l}76 \\
77\end{array}$ & $\begin{array}{l}50 \\
52\end{array}$ & $\begin{array}{l}100 \\
100\end{array}$ & $\begin{array}{l}0.92 \\
0.51\end{array}$ & $\begin{array}{l}5.8 \\
5.1\end{array}$ & $\begin{array}{l}-\quad 29 \\
-\quad 4\end{array}$ \\
\hline $\begin{array}{l}9 \\
9\end{array}$ & $\begin{array}{l}76 \\
77\end{array}$ & $\begin{array}{l}98 \\
82\end{array}$ & $\begin{array}{l}100 \\
100\end{array}$ & $\begin{array}{l}0.43 \\
0.63\end{array}$ & $\begin{array}{l}5.6 \\
5.8\end{array}$ & $\begin{array}{l}-76 \\
-108\end{array}$ \\
\hline $\begin{array}{l}10 \\
10\end{array}$ & $\begin{array}{l}76 \\
77\end{array}$ & $\begin{array}{l}66 \\
66\end{array}$ & $\begin{array}{l}50 \\
50\end{array}$ & $\begin{array}{l}0 \cdot 23 \\
0 \cdot 10\end{array}$ & $\begin{array}{l}2 \cdot 4 \\
4 \cdot 3\end{array}$ & $\begin{array}{r}-\quad 7 \\
33\end{array}$ \\
\hline 11 & 77 & 50 & 50 & $0 \cdot 14$ & 3.9 & -5 \\
\hline $\begin{array}{l}12 \\
12\end{array}$ & $\begin{array}{l}76 \\
77\end{array}$ & $\begin{array}{l}56 \\
90\end{array}$ & $\begin{array}{r}61 \\
100\end{array}$ & $\begin{array}{l}0.85 \\
1.35\end{array}$ & $\begin{array}{l}5.9 \\
4.5\end{array}$ & $\begin{array}{l}-53 \\
-35\end{array}$ \\
\hline $\begin{array}{l}13 \\
13\end{array}$ & $\begin{array}{l}76 \\
77\end{array}$ & $\begin{array}{l}173 \\
177\end{array}$ & $\begin{array}{r}93 \\
100\end{array}$ & $\begin{array}{l}0.69 \\
0.77\end{array}$ & $\begin{array}{l}5.1 \\
4.5\end{array}$ & $\begin{array}{l}-37 \\
-73\end{array}$ \\
\hline $\begin{array}{l}14 \\
14\end{array}$ & $\begin{array}{l}76 \\
77\end{array}$ & $\begin{array}{l}76 \\
81\end{array}$ & $\begin{array}{l}61 \\
53\end{array}$ & $\begin{array}{l}0.20 \\
0.25\end{array}$ & $\begin{array}{l}3 \cdot 7 \\
4 \cdot 2\end{array}$ & $\begin{array}{r}6 \\
-83\end{array}$ \\
\hline $\begin{array}{l}15 \\
15\end{array}$ & $\begin{array}{l}76 \\
77\end{array}$ & $\begin{array}{r}3 \\
23\end{array}$ & $\begin{array}{r}100 \\
93\end{array}$ & $\begin{array}{l}0.47 \\
0.34\end{array}$ & $\begin{array}{l}4.9 \\
5 \cdot 1\end{array}$ & $\begin{array}{l}-71 \\
-40\end{array}$ \\
\hline $\begin{array}{l}16 \\
16\end{array}$ & $\begin{array}{l}76 \\
77\end{array}$ & $\begin{array}{l}145 \\
174\end{array}$ & $\begin{array}{l}35 \\
35\end{array}$ & $\begin{array}{l}0.24 \\
0.32\end{array}$ & $\begin{array}{l}4 \cdot 3 \\
5 \cdot 0\end{array}$ & $-\begin{array}{r}21 \\
5\end{array}$ \\
\hline 17 & 77 & 155 & 35 & 0.61 & $4 \cdot 6$ & -34 \\
\hline $\begin{array}{l}18 \\
18\end{array}$ & $\begin{array}{l}76 \\
77\end{array}$ & $\begin{array}{r}29 \\
222\end{array}$ & $\begin{array}{l}35 \\
35\end{array}$ & $\begin{array}{l}0.44 \\
0.38\end{array}$ & $\begin{array}{l}1 \cdot 4 \\
4 \cdot 1\end{array}$ & $\begin{array}{r}3 \\
14\end{array}$ \\
\hline $\begin{array}{l}19 \\
19\end{array}$ & $\begin{array}{l}76 \\
77\end{array}$ & $\begin{array}{l}37 \\
43\end{array}$ & $\begin{array}{l}100 \\
100\end{array}$ & $\begin{array}{l}0.85 \\
0.64\end{array}$ & $\begin{array}{l}4.9 \\
5.9\end{array}$ & $\begin{array}{l}-45 \\
-50\end{array}$ \\
\hline 20 & 76 & 90 & 35 & 0.54 & $2 \cdot 4$ & -81 \\
\hline $\begin{array}{l}21 \\
21\end{array}$ & $\begin{array}{l}76 \\
77\end{array}$ & $\begin{array}{l}46 \\
54\end{array}$ & $\begin{array}{l}50 \\
50\end{array}$ & $\begin{array}{l}0.22 \\
0.22\end{array}$ & $\begin{array}{l}3.1 \\
5.5\end{array}$ & $\begin{array}{r}35 \\
-\quad 52\end{array}$ \\
\hline $\begin{array}{l}22 \\
22\end{array}$ & $\begin{array}{l}76 \\
77\end{array}$ & $\begin{array}{l}73 \\
67\end{array}$ & $\begin{array}{l}89 \\
90\end{array}$ & $\begin{array}{l}0.85 \\
1.09\end{array}$ & $\begin{array}{l}6.0 \\
6 \cdot 4\end{array}$ & $\begin{array}{l}-114 \\
-139\end{array}$ \\
\hline 23 & 77 & 35 & 35 & 0.20 & $5 \cdot 1$ & -35 \\
\hline
\end{tabular}

